\title{
What to do to defend themselves: description of three defensive strategies displayed by a serpent Dipsas alternans (Fischer, 1885) (Serpentes, Dipsadidae)
}

\author{
Thiago Maia-Carneiro* \\ Milena Wachlevski \\ Carlos Frederico D. Rocha \\ Departamento de Ecologia, Universidade do Estado do Rio de Janeiro \\ Rua São Francisco Xavier 524, CEP 20550-019, Rio de Janeiro - RJ, Brazil \\ *Corresponding author \\ thiagomaianc@gmail.com
}

Submetido em 10/04/2011

Aceito para publicação em 14/10/2011

\section{Resumo}

O que fazer para se defender: descrição de três estratégias defensivas exibidas por uma serpente Dipsas alternans (Fischer, 1885) (Serpentes, Dipsadidae). Mecanismos que envolvem interações entre presa e predador são elementos importantes atuando sobre a História Natural das espécies envolvidas. Comportamentos defensivos exibidos por serpentes evoluíram como uma forma de evitar que sejam detectadas, feridas ou mortas. Dipsas alternans é uma espécie de serpente que ocorre na Mata Atlântica brasileira e pode mostrar diferentes comportamentos defensivos em diferentes situações. Uma fêmea adulta de $D$. alternans foi encontrada no Parque

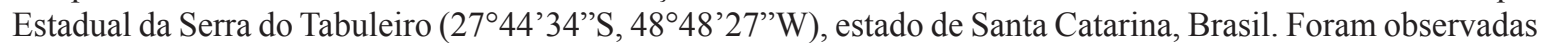
três estratégias defensivas exibidas pela serpente (imobilidade, enrolamento corpóreo e esconder a cabeça), que são relatadas pela primeira vez para $D$. alternans e podem ser de grande importância para reduzir a chance de esta ser predada.

Palavras-chave: Dipsas alternans, Enrolamento corpóreo, Esconder a cabeça, Imobilidade, Mecanismos defensivos

\section{Abstract}

Mechanisms involving interactions between prey and predator are important elements acting on the Natural History of the species concerned. Defensive behaviors presented by serpents evolved as a way for them to avoid being detected, injured, or killed. Dipsas alternans is a serpent species occurring in the Brazilian Atlantic Rainforest and it can show distinct defensive behaviors in different situations. An adult female of D. alternans

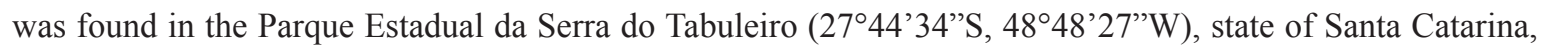
Brazil. Three defensive strategies were presented by the serpent (immobility, coil body, and hide head), which are reported for the first time with regard to D. alternans and can be of great importance to reduce its chance to be preyed.

Key words: Coil body, Defensive mechanisms, Dipsas alternans, Hide head, Immobility 
In general, mechanisms mediating interactions between prey and predator are important elements acting on the Natural History of the species concerned, and understanding them contributes to the development of evolutionary biology and ecological studies. Defensive behaviors exhibited by serpents evolved as a way for them to avoid being detected, injured, or killed, and they present a great variety, once a species, or even a single individual, can demonstrate different anti-predator behaviors, depending on the occasion (GREENE, 1988).

Dispsadidae constitute a primarily tropical Family of serpents restricted to the New World, with higher species diversity recorded in Central America, South America, and West Indies (OLIVEIRA et al., 2008; VIDAL et al., 2010). A recent study approaching taxonomy of snail-eaters serpents from the genus Dipsas (HARVEY, 2008) recognized eight species groups, four of them occurring in Brazil: Dipsas variegata (Duméril, Bibron and Duméril, 1854), D. catesbyi (Sentzen, 1796), D. indica Laurenti, 1768, and D. incerta (Jan, 1863) (BÉRNILS, 2010). This last group includes Dipsas alternans, which occurs in the Brazilian Atlantic Rainforest from the state of Espírito Santo to the state of Rio Grande do Sul (PASSOS et al., 2004; HARVEY, 2008), and it can show distinct defensive behaviors in different situations.

Studies approaching defensive behaviors displayed by snakes report different tactics used by a given species (e.g. MARTINS, 1996; CADLE; MYERS, 2003; MARTINS et al., 2008), even from the tribe Dipsadini (sensu VIDAL et al., 2010). Herein, we report three defensive strategies presented by $D$. alternans in the Atlantic Rainforest, increasing the knowledge on the biology of this species.

An adult female of Dipsas alternans, measuring $414 \mathrm{~mm}$ of snout-vent length, tail length of $166 \mathrm{~mm}$ and mass of $14 \mathrm{~g}$, was found and collected at 08:33p.m. in an area of dense ombrophilous forest of the Parque Estadual da Serra do Tabuleiro (2744'34"S, $\left.48^{\circ} 48^{\prime} 27^{\prime \prime} \mathrm{W}\right)$, in the municipality of Santo Amaro da Imperatriz, state of Santa Catarina, Brazil, on October 6,2008 . The individual, which was seen still moving climbing a little tree, in the moment the observer got closer, remained immobile. Immobility is a widespread behavior of initial response in arboreal serpents (such as Dipsas alternans), in which the individuals remain immobile but not rigid or unresponsive, either in a retreat or exposed and alert (GREENE, 1988). This behavior can be confused with tonic immobility, when the animal assumes a state of unresponsiveness to stimulation, which is apparently rare as a naturally occurring behavior (GREENE, 1988).

Another defensive behavior presented by the serpent in the presence of observers consisted of hiding its head and neck under its coiled body, forming a spherical shape, and then the brown spots present on the dorsal region of the head (parietal spots) were exposed by the serpent (Figure 1). In some cases, coil body can be rapidly formed, uncoiled, and reformed (GREENE, 1988), however, that was not observed in this case.

The $D$. alternans found had characteristics that distinguished it from the majority of the individuals of the same species, which possess a head mostly immaculate except for a pair of parietal spots (PASSOS et al., 2004; HARVEY, 2008; personal observation), although the individual found had three parietal spots (two with well defined borders and one no delimitated by borders) instead of two (Figure 1). The occurrence of a third parietal spot in D. alternans has been observed, it can be present or absent and also vary in form and size (R.S. BÉRNILS personal communication).

These defensive strategies reported here (immobility, coil body, and hide head) are known to some Dispsadini species (see MARTINS, 1996; MARQUES et al., 2001; CADLE; MYERS, 2003; MARTINS et al., 2008) and are reported for the first time to Dipsas alternans. As this species might be prey for other species (MARQUES; PUORTO, 1994), these defensive mechanisms may be of importance to reduce the chance to be preyed, allowing the maintenance of the physical integrity of the individuals. Voucher specimen of the serpent (MNRJ 20249) was deposited in the herpetological collection of Museu Nacional, in Rio de Janeiro. 
FIGURE 1: Dipsas alternans positioned in a spherical form hiding its head and exposing its parietal spots (Photo by T. Maia-Carneiro).

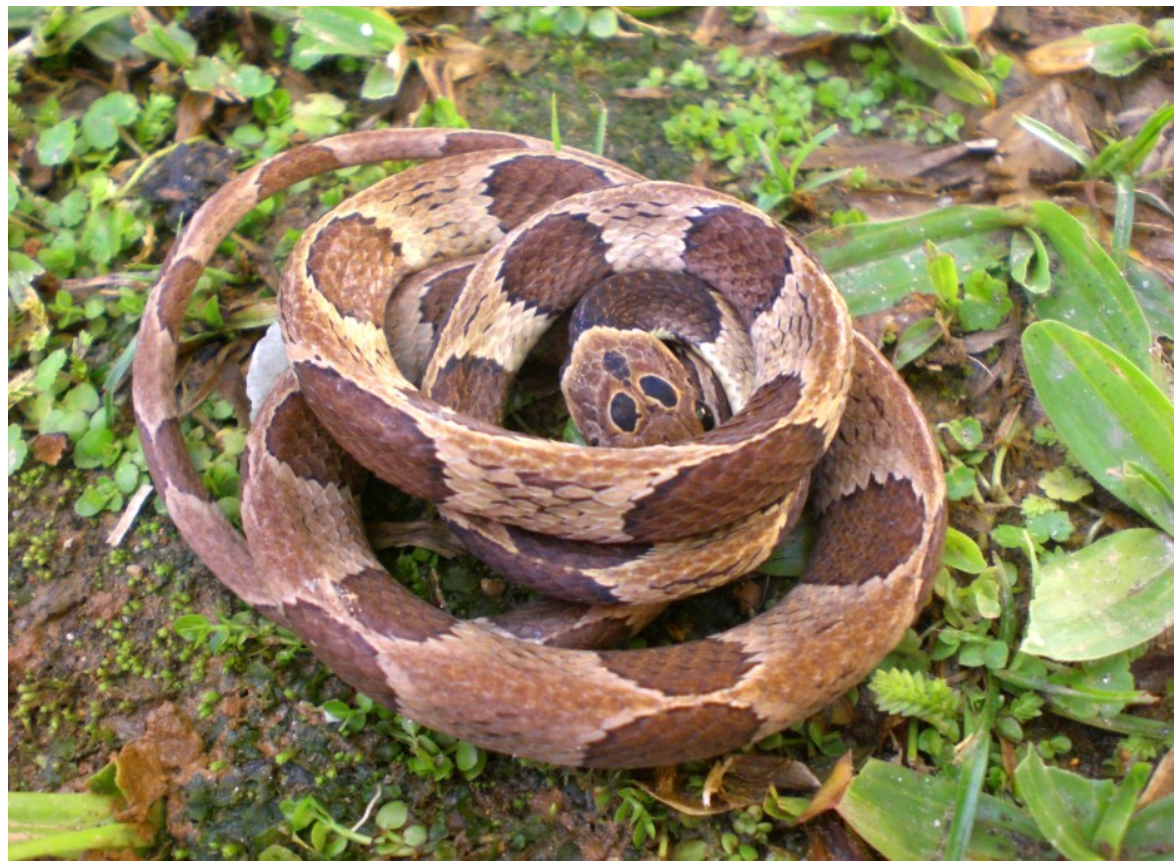

\section{Acknowledgements}

We thank R. S. Bérnils, who kindly revised a first draft of the manuscript and offered helpful suggestions. We also thank P. Passos, for the help in the species identification. This study was supported by research grants from the Conselho Nacional de Desenvolvimento Científico e Tecnológico (CNPq) (Processes 304791/2010-5 and 470265/2010-8) and from the Fundação Carlos Chaga Filho de Amparo à Pesquisa do Estado do Rio de Janeiro (Faperj) through the program "Cientistas do Nosso Estado" (Process E-26/102.404.2009) to C. F. D. Rocha. T. Maia-Carneiro and M. Wachlevski received MsC. and Ph.D. grants, respectively, from Coordenação de Aperfeiçoamento de Pessoal de Nível Superior (Capes). Specimens were collected under Collecting Permit number 1448 from SISBIO/Instituto Chico Mendes and Fundação do Meio Ambiente de Santa Catarina (Fatma).

\section{References}

BÉRNILS, R. S. (Org.). 2010. Brazilian reptiles - List of species. Sociedade Brasileira de Herpetologia. Available at $<$ http://www. sbherpetologia.org.br/>. Acessed on: 7 Feb. 2011.
CADLE, J. E.; MYERS, C. W. Systematics of snakes referred to Dipsas variegata in Panama and Western South America, with revalidation of two species and notes on defensive behaviors in the Dipsadini (Colubridae). American Museum Novitates, New York, v. 3409, p. 47, 2003.

GREENE, H. W. Anti-predator mechanisms in reptiles. In: GANS, C.; HUEY, R. B. (Ed.). Biology of the Reptilia 16. New York: Allan R. Liss, 1988. p. 1-152.

HARVEY, M. B. New and poorly known Dipsas (Serpentes: Colubridae) from northern South America. Herpetologica, Lawrence, v. 64, n. 4, p. 422-451, 2008.

MARQUES, O. A. V.; PUORTO, G. Dieta e comportamento alimentar de Erythroplampus aesculapii, uma serpente ofiófaga. Revista Brasileira de Biologia, São Carlos, v. 54, n. 2, p. 253259,1994 .

MARQUES, O. A. V.; ETEROVIC, A.; SAZIMA, I. Serpentes da Mata Atlântica. Guia ilustrado para a Serra do Mar. Ribeirão Preto: Editora Holos, 2001. 184 p.

MARTINS, M. Defensive tactics in lizards and snakes: The potential contribution of the Neotropical fauna. In: ENCONTRO ANUAL DE ETOLOGIA, 14, 1996, Uberlândia. Anais... Uberlândia: EAE, 1996. p. 185-199.

MARTINS, M.; MARQUES, O. A. V.; SAZIMA, I. How to be arboreal and diurnal and still stay alive: microhabitat use, time of activity, and defense in Neotropical forest snakes. South American Journal of Herpetology, São Paulo, v. 3, n. 1, p. 60-69, 2008.

OLIVEIRA, L.; JAREDA, C.; PRUDENTEB, A. L. C.; ZAHERC, H.; ANTONIAZZI, M. M. Oral glands in dipsadine "goo-eater" snakes: Morphology and histochemistry of the infralabial glands 
in Atractus reticulatus, Dipsas indica, and Sibynomorphus mikanii. Toxicon, Glasgow, v. 51, p. 898-913, 2008.

PASSOS, P.; FERNANDES, D. S.; CARAMASCHI, U. The taxonomic status of Leptognathus incertus Jan, 1863, with revalidation of Dipsas alternans (Fischer, 1885) (Serpentes: Colubridae: Dipsadinae). Amphibia-Reptilia, Leiden, v. 25, p. 381-393, 2004.

VIDAL, N.; DEWYNTER, M.; GOWER, D. J. Dissecting the major American snake radiation: A molecular phylogeny of the Dipsadidae Bonaparte (Serpentes, Caenophidia). Comptes Rendus Biologies, Paris, v. 333, n. 1, p. 48-55, 2010. 